\title{
Erratum
}

\section{Effect of exposure to 2,5-hexanediol in light or darkness on the retina of albino and pigmented rats. I. Morphology}

\author{
Birgitta Bäckström¹, Per Nylén'2, Maud Hagman², Ann-Christin Johnson², Gunnar Höglund², \\ and V. Peter Collins ${ }^{3,4}$
}

Arch Toxicol (1993) 67: 277-283

Due to an unfortunate error introduced after the proofs had been corrrected by the authors, the symboles in the legend for Fig. 2 and the \pm sign in Table 2 were incorrectly replaced by other symbols.

The correct versions are reprinted below.
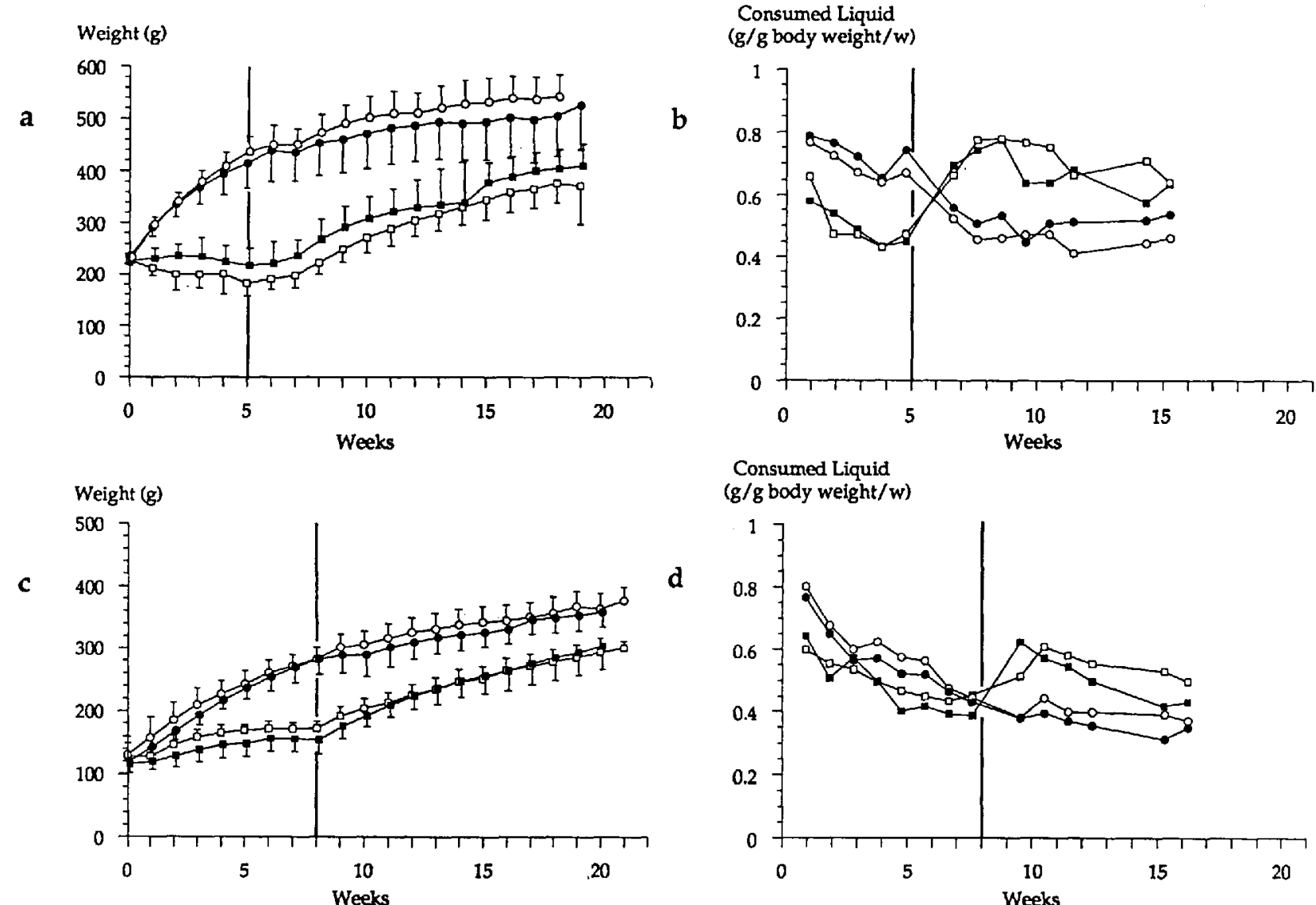

Consumed Liquid

( $g / g$ body weight/w)

d

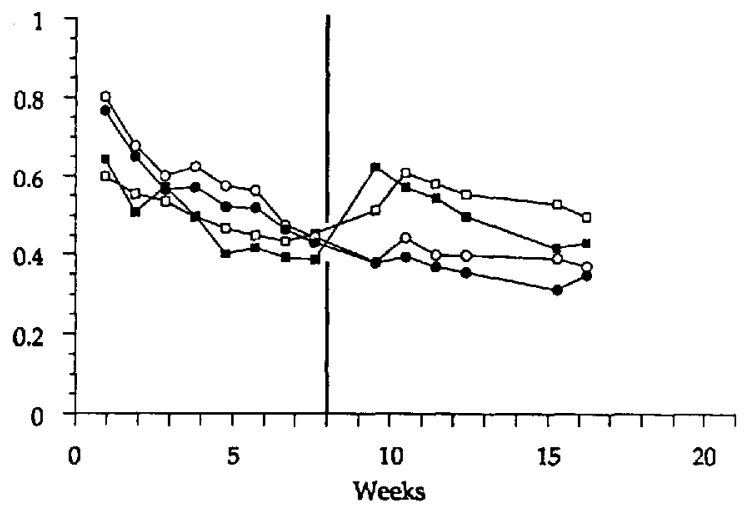

Fig. 2. Weight gain (a, $\mathbf{c})$ and liquid consumption (b, d) of male albino (a and $\mathbf{b}$ ) and pigmented rats (c and d) exposed/not exposed to 2,5-hexanediol $(\mathrm{H}, 1 \% ; 5$ and 8 weeks, respectively) in drinking water. Rats either exposed to $\mathrm{H}$ and light $[12 \mathrm{~h}$ light $/ 2 \mathrm{~h}$ darkness; $L H(\square)]$, or exposed to light without $\mathrm{H}[L C(\mathrm{O})]$, or exposed to $\mathrm{H}$ and kept in constant darkness $[D H(\boldsymbol{\square})]$, or kept in constant darkness without $\mathrm{H}[D C(\mathbf{O})]$. Measurements made $2-5$ days and 13 weeks after exposure to $H$, or at corresponding time for groups not exposed to $\mathrm{H}$. Means and SD. Start of

exposure to $\mathrm{H}(\mathrm{LH}, \mathrm{DH})$ at week 0 . Vertical bar indicates termination of exposure to $H$. Note that 1 ) weight gain was absent (a) or slight (c) during exposure to $\mathrm{H}(\mathrm{LH}, \mathrm{DH}) ; 2$ ) liquid consumption (g/g body weight/week), at least in albino rats during exposure to $\mathrm{H}(\mathrm{LH}, \mathrm{DH})$, was lower than in other groups, and that consumption was larger after the end of exposure to $\mathrm{H}$; and 3) intake of $\mathrm{H} / \mathrm{g}$ body weight/week was little affected by light exposure (SD for liquid consumption not shown, since data points show consumption per cage, i. e. per 4 rats) 
Table 2. Number of nuclei per $100 \mu \mathrm{m}$ in outer nuclear layer (ONL) and relative thickness of outer plexiform layer (OPL) in albino and pigmented male rats exposed/not exposed to 2,5-hexanediol $(\mathrm{H}, 1 \% ; 5$ and 8 weeks, respectively) in drinking water. Rats either exposed to $\mathrm{H}$ and light ( $12 \mathrm{~h}$ light/ $12 \mathrm{~h}$ darkness; $\mathrm{LH}$ ), or exposed to light without $\mathrm{H}$ (LC), or exposed to $\mathrm{H}$ and kept in constant darkness (DH), or kept in constant darkness without $H$ (DC). Observations made immediately and 13 weeks after exposure to $\mathrm{H}$, or at corresponding time for groups not exposed to H. Relative thickness of OPL calculated as thickness $(\mu \mathrm{m})$ of OPL divided by summated thickness of inner nuclear layer, inner plexiform layer and ganglion cell layer. Data are means and SD

\begin{tabular}{|c|c|c|c|}
\hline \multirow{2}{*}{$\begin{array}{l}\text { Expo- } \\
\text { sure } \\
\text { group }\end{array}$} & \multicolumn{2}{|l|}{ Albino rats } & \multirow{2}{*}{$\frac{\text { Pigmented rats }}{\text { ONL }}$} \\
\hline & ONL & OPL & \\
\hline \multicolumn{4}{|c|}{ Immediately after $H$} \\
\hline LH & $209 \pm 49 \mathrm{LC}, \mathrm{DH}, \mathrm{DC}$ & - & $a 314 \pm 23$ \\
\hline LC & $258 \pm 34^{\mathrm{LH}}, \mathrm{DC}$ & - & $288 \pm 28^{\mathrm{DC}}$ \\
\hline $\mathrm{DH}$ & $288 \pm 39^{\mathrm{LH}}$ & - & $295 \pm 24 \mathrm{DC}$ \\
\hline DC & $304 \pm 19 \mathrm{LH}, \mathrm{LC}$ & - & $336 \pm 56^{\mathrm{LC}, \mathrm{DH}}$ \\
\hline \multicolumn{4}{|c|}{13 weeks after $H$} \\
\hline LH & $\mathrm{b} 116 \pm 56^{\mathrm{LC}, \mathrm{DH}, \mathrm{DC}}$ & $\mathrm{b} 0.045 \pm 0.025^{\mathrm{LC}, \mathrm{DH}, \mathrm{DC}}$ & $239 \pm 20^{L C}, D C$ \\
\hline LC & $234 \pm 30^{\mathrm{LH}}$ & $0.081 \pm 0.020^{\mathrm{LH}, \mathrm{DH}, \mathrm{DC}}$ & $292 \pm 27 \mathrm{LH}, \mathrm{DH}$ \\
\hline $\mathrm{DH}$ & $234 \pm 14^{L H}$ & $0.116 \pm 0.029 \mathrm{LH}, \mathrm{LC}$ & $239 \pm 28 \mathrm{LC}, \mathrm{DC}$ \\
\hline $\mathrm{DC}$ & $258 \pm 21^{\mathrm{LH}}$ & $0.119 \pm 0.023^{\mathrm{LH}, \mathrm{LC}}$ & $279 \pm 32^{\mathrm{LH}, \mathrm{DH}}$ \\
\hline
\end{tabular}

Groups to the right above data (LH, LC, DH, or DC) indicate that these groups differ $(p<0.05)$ from group for which data is presented. Symbols $\mathrm{a}$ or $\mathrm{b}$ at left above data indicates non-additive interaction between $\mathrm{H}$ and light; ${ }^{\mathrm{a}}=p<0.05,{ }^{\mathrm{b}}=p<0.001$ 